\title{
Lessons from the Shoah for history, memory, and human rights
}

\author{
Clementina Acedo
}

Published online: 25 June 2010

(C) UNESCO IBE 2010

Around the world, Holocaust education is entangled with contemporary political controversies and geopolitical struggles. The historical legacy of anti-Semitism and the on-going conflict in Israel and Palestine contribute to this emotionally and politically charged debate. As a consequence, teachers and others involved in education may not feel well equipped to handle the subject.

Even advocates of Holocaust education differ greatly in their basic conceptualizations of the topic, on its place in the curriculum, and on its significance in their teaching. In European countries, the focus on the Holocaust is embedded in the teaching of history, due to its historical and contextual significance; however, in some developing and emerging countries that are seeking to develop more international or world-society perspectives, the topic is more relevant as an element in citizenship education and is linked to the teaching of universal human rights. Bromley and Russell, and Eckmann, both in this issue, point this out. For these reasons, Holocaust education is often justified not on the basis of its historical significance, but as a way to guide individual and collective conduct in order to oppose bigotry in the present and future. Holocaust education can make a great contribution if its lessons help to protect human rights, and if they counteract hostility and discrimination along such too-common demarcations as class, disability, ethnicity, faith, gender, and sexual orientation. Is this justification for studying the Holocaust borne out by its practice in schools?

This special issue includes important contributions and new insights from researchers who have examined the practices of Holocaust education in various parts of the world. An open call for papers for this issue brought more than 30 contributions, a pool of highquality papers that greatly exceeded our expectations, so much so that we decided to produce a double issue on the topic. The broad interest and new research is a testimony both to the significance of the field and to its challenges.

The meaning and significance of Holocaust education vary with the peoples to whom and the places where it is taught. While the Holocaust was a catastrophic and devastating event, it is also the most researched and documented genocide in human history, and

C. Acedo $(\bowtie)$

IBE-UNESCO, P.O. Box 199, 1211 Geneva 20, Switzerland

e-mail: c.acedo@ibe.unesco.org 
therefore provides important lessons for peace makers. As UNESCO's main mission is to contribute to "building peace in the minds of people", the articles in this issue carry direct lessons from school and classroom practices not only for countries in Europe but also for human rights and peace education worldwide.

Primo Levi, an Italian writer and Holocaust survivor, suggested that we cannot understand the Holocaust, but we can and must understand its roots and be on our guard lest they begin to grow again. The ongoing genocides of the late 20th and early $21 \mathrm{st}$ century demonstrate that we are not safe from large-scale dehumanization and slaughter. The conviction that education about the causes of the Holocaust could prevent future occurrences helps to explain the urgency behind efforts to promote this type of study.

In a time of increasing globalization and migration, when many societies have reached unprecedented levels of cultural diversity, resurgent nationalism and xenophobia can remind people of the events that led to the Shoah, and thus underscore the urgency of this educational mission. Given the combination of changing circumstances around the world today, the loss of so many survivors of the Holocaust-along with their memories-and the great hopes that effective education will have transformative power after such tragic events, this systematic study of a terrible genocide creates compelling and valuable insights.

United Nations resolution 60/7 designated 27 January as an annual "International Day of Commemoration in memory of the victims of the Holocaust"; it "urges Member States to develop educational programmes that will inculcate future generations with the lessons of the Holocaust in order to help to prevent future acts of genocide". These efforts are underway in diverse forms around the world, and require careful examination.

Further, normative questions are much debated in Holocaust education: what should be the lessons of the Holocaust? Who should learn about it? At what age? Is the Holocaust qualitatively or quantitatively unique, and worthy of attention beyond other genocides in human history, or beyond the historical sufferings of any given minority group? In the midst of these heated controversies and moral debates, sober study of what is actually taking place is essential both to inform these discussions and to ground them in empirical realities. This issue of Prospects contributes empirical research about the actual policies and practice of Holocaust education in countries and classrooms around the world.

Finally, it is fitting to discuss the word "Holocaust" itself. It is known around the world, and for more than a half century has invoked a vision of the very worst in humankind. But words matter and naming is an exercise of power. Some of the authors in this issue have questioned the very term "Holocaust education", and made disclaimers based on its ambiguity, or offered terms that may be more appropriate in other languages. With them, I personally think that "Holocaust education" carries ambivalent connotations, is not well defined, and lacks analytical power. Eckmann, in this issue, claims that because the term carries a theological connotation and lacks analytical meaning, it can be more mystifying than clarifying. It is also most widely used amongst British and American academics. Holocaust refers more commonly to the extermination of European Jewry, but it may also include the murder of Sinti, Roma, Poles, Russians, homosexuals, Communists, those with disabilities and others under the Nazi regime; this is one reason why some people do not find it appropriate. (Heyl 1997a, cited in Boschki, Reichmann, and Schwendemann, in this volume). Speakers of French, German and Hebrew prefer to use the term "Shoah", which means catastrophe in Hebrew. Others prefer the use of "hurban", meaning also catastrophe in Yiddish. Many prefer the word "genocide". In Germany, since Theodor Adorno gave his famous speech on Education after Auschwitz, the term "teaching after and about Auschwitz" has come to represent a general effort to resist "inhumanity" and an approach 
to learning about and understanding human rights as part of a European global vision, according to Boschki et al.

I would like to express my appreciation for the remarkable work done by the guest editors Zehavit Gross and Doyle Stevick. Along with Reinhold Boschki, they attracted the attention of the Nobel Prize laureate Elie Wiesel to this collective work; I also thank him for his generosity and enthusiasm. Wiesel's appreciation for this work and his profound belief in education are expressed in the letter below. His words are more eloquent than mine: whatever is the response to the essential questions which our society confronts today; education must be the main way to respond to them. 